\title{
Neuronal Colocalization of Peptides, Catecholamines, and Catecholamine-Synthesizing Enzymes in Guinea Pig Paracervical Ganglia
}

\author{
Judith L. Morris and lan L. Gibbins \\ Department of Anatomy and Histology, and Centre for Neuroscience, Flinders University of South Australia, Bedford Park, \\ SA 5042, Australia
}

The patterns of colocalization of neuropeptides, catecholamines, and catecholamine-synthesizing enzymes were examined in principal neurons and nerve terminals in guinea pig paracervical ganglia using a double-labeling immunohistochemical procedure. A small proportion of nerve cell bodies $(<10 \%)$ had the characteristics of catecholaminesynthesizing neurons and presumably were noradrenergic. Another $50 \%$ of the nerve cell bodies contained immunoreactivity (IR) to dopamine- $\beta$-hydroxylase (DBH), but did not have any other characteristics of noradrenergic neurons; they did not contain detectable catecholamines, or IR to dopa decarboxylase (DDC) or tyrosine (TH) hydroxylase, nor did they take up exogenous catecholamines. Half of the catecholamine neurons had neuropeptide $Y$ (NPY)-IR, and a small number ( $0.5 \%$ total neurons) had somatostatin (Som)-IR. Most of the non-noradrenergic neurons with DBH-IR (40-50\% total neurons) contained IR for dynorphin (Dyn), NPY, and vasoactive intestinal peptide (VIP), and about half of them (20$25 \%$ total) also contained Som-IR. Ten to twenty percent of neurons contained IR to Som, but not to any other antigen examined here. Nerve terminals with substance P (SP)-IR or enkephalin (Enk)-IR were prominent in all ganglia. SP-IR fibers formed dense baskets only around those neurons with DBH/Dyn/NPY/VIP ( \pm Som)-IR, while fibers with very bright Enk-IR were associated selectively with those neurons with Som-IR alone. In addition, most TH-IR nerve cell bodies were surrounded by NPY-IR varicose nerve fibers. In conclusion, this analysis of combinations of peptides and enzymes contained in principal neurons of the paracervical ganglia allows us to identify as many as 11 different neuron populations. The functional significance of the presence of the same neuropeptide (e.g., NPY) in different neuron populations is as yet unknown. Some of these classes of neurons are associated specifically with immunohistochemically distinct

\footnotetext{
Received Dec. 9, 1986; revised Feb. 25, 1987; accepted Apr. 7, 1987.

This work was supported by grants from the National Heart Foundation and the N.H. and M.R.C. of Australia. We are grateful to Professors M. Costa and J. B. Furness for their advice and constructive comments on the manuscript. Drs. R. A. Rush and I. Ferguson are thanked for helpful discussions. We are indebted to those individuals named in Table 1 for the generous provision of antisera; to Pat Vilimas, Sue Graham, Fiona Renton, and Janine Falconer for excellent technical assistance; and to Rae Tyler and Michele Hoffmann for typing the manuscript.

Correspondence should be addressed to Dr. Morris at the above address. Copyright (C) 1987 Society for Neuroscience $0270-6474 / 87 / 103117-14 \$ 02.00 / 0$
}

types of presynaptic nerve fibers, which suggests that different immunohistochemically defined classes of neurons represent different functional pathways.

The anterior pelvic ganglia contain both noradrenergic and nonnoradrenergic neurons that supply axons to the reproductive organs, bladder, ureter, and associated blood vessels (see Bell, 1968, 1974; Kanerva, 1972; Costa and Furness, 1973; Owman et al., 1983; Mattiasson et al., 1985). In females these ganglia are associated with the distal segments of the hypogastric nerves immediately lateral to the junction between the uterine cervix and the vagina, and are known as paracervical ganglia or Frankenhäuser's ganglia. At least some of these nerve cell bodies have been shown histochemically to be noradrenergic (Kanerva, 1972; Thorbert et al., 1977), and physiological studies have shown that paracervical neurons supply a cholinergic vasodilator innervation to the uterine artery (Bell, 1968, 1974). Recent immunohistochemical studies on rats, cats, and guinea pigs have demonstrated inmmunoreactivity to vasoactive intestinal peptide (VIP), and neuropeptide Y (NPY) in a subpopulation of paracervical ganglion neurons (Alm et al., 1980a; Helm et al., 1981; Schultzberg et al., 1983; Gu et al., 1984; Inyama et al., 1985). VIP and NPY coexist in a small proportion of these neurons in rats (Inyama et al., 1985). These paracervical neurons are the likely sources of at least some axons with VIP- or NPYlike immunoreactivity in the female genital tract (Alm et al., 1980b; Helm et al., 1981; Gu et al., 1984; Papka et al., 1985), as well as of the non-noradrenergic neurons with immunoreactivity to NPY, VIP and dynorphin (Dyn) in the guinea pig main uterine artery (Morris et al., 1985).

Increasing evidence has been presented for well-defined patterns of colocalization of several different regulatory peptides (RPs) and nonpeptide transmitters in neurons of many peripheral ganglia (e.g., Lundberg et al., 1982a; Costa and Furness, 1984; Furness et al., 1984; Macrae et al., 1986; Gibbins et al., $1987 \mathrm{a}, \mathrm{b})$. These patterns of colocalization have been correlated both with the peripheral targets of the neurons and with the types of presynaptic nerve fibers associated with the postganglionic neurons (Schultzberg et al., 1983; Heym et al., 1984; Morris et al., 1986b). Because of our interest in the roles of peptides in neurons supplying the uterine artery and other pelvic blood vessels, in the present study we have investigated the neuronal colocalization of peptides, transmitter-synthesizing enzymes, and catecholamines in the paracervical ganglia in order to define the number and types of neuronal populations in 


\begin{tabular}{|c|c|c|c|c|}
\hline Antigen raised against & Antibody code & Host species & Dilution & Supplier \\
\hline $\begin{array}{l}\text { CGRP (rats } 28-37 \text { ) } \\
\text { Calcitonin gene-related peptide }\end{array}$ & Mac I & Rabbit & $1: 2000$ & $\begin{array}{l}\text { Dr. I. MacIntyre } \\
\text { (Morris et al., 1984) }\end{array}$ \\
\hline $\begin{array}{l}\text { DDC (porcine kidney) } \\
\text { Dopa decarboxylase }\end{array}$ & - & Rabbit & $1: 200$ & $\begin{array}{l}\text { Dr. C. Bell } \\
\text { (Muller et al., 1984) }\end{array}$ \\
\hline \multirow[t]{2}{*}{$\begin{array}{l}\text { DBH (bovine adrenal) } \\
\text { Dopamine- } \beta \text {-hydroxylase }\end{array}$} & 2D4 & Rabbit & $1: 400$ & $\begin{array}{l}\text { Dr. R. A. Rush } \\
\text { (Rush and Geffen, 1980) }\end{array}$ \\
\hline & 2012 & Rabbit & $1: 400$ & Eugene Tech., NJ \\
\hline $\begin{array}{l}\text { Dyn }(1-13) \\
\text { Dynorphin }\end{array}$ & Paul & Rabbit & $1: 100$ & $\begin{array}{l}\text { Dr. A. Goldstein } \\
\text { (Morris et al., 1985) }\end{array}$ \\
\hline $\begin{array}{l}\text { Leu-Enk } \\
\text { Enkephalin }\end{array}$ & $\mathrm{NOCl}$ & $\begin{array}{l}\text { Mouse } \\
\text { (monoclonal) }\end{array}$ & $1: 400$ & $\begin{array}{l}\text { Seralab } \\
\quad \text { (Cuello et al., 1984) }\end{array}$ \\
\hline \multirow[t]{3}{*}{$\begin{array}{l}\text { NPY (porcine) } \\
\text { Neuropeptide Y }\end{array}$} & E2210 & Sheep & $1: 800$ & $\begin{array}{l}\text { Drs. W. Blessing and J. Oliver } \\
\text { (Blessing et al., 1986) }\end{array}$ \\
\hline & NPY F1/V1 & Rat & $1: 200$ & $\begin{array}{l}\text { Dr. R. Murphy } \\
\text { (Morris et al., 1986d) }\end{array}$ \\
\hline & RMJ 263 & Rabbit & $1: 1600$ & $\begin{array}{l}\text { Drs. C. Maccarrone and B. Jarrott } \\
\text { (Maccarrone and Jarrott, 1985; } \\
\text { Morris et al., 1986c) }\end{array}$ \\
\hline Som $(1-14)$ & $18 \mathrm{~J} 22$ & Rabbit & $1: 2000$ & Dr. F. Vandesande \\
\hline Somatostatin & S8 & Mouse & $50 \mu \mathrm{g} / \mathrm{ml}$ & $\begin{array}{l}\text { Dr. A. Buchan } \\
\quad \text { (Buchan et al., 1985) }\end{array}$ \\
\hline \multirow[t]{2}{*}{$\begin{array}{l}\text { SP } \\
\text { Substance P }\end{array}$} & RMSP-1 & Rabbit & $1: 2000$ & $\begin{array}{l}\text { Dr. R. Murphy } \\
\text { (Morris et al., 1986b) }\end{array}$ \\
\hline & $\mathrm{NCl} / 34 \mathrm{HL}$ & Rat (monoclonal) & $1: 800$ & $\begin{array}{l}\text { Seralab } \\
\quad \text { (Cuello et al., 1979) }\end{array}$ \\
\hline $\begin{array}{l}\text { IH (bovine adrenal) } \\
\text { Tyrosine hydroxylase }\end{array}$ & 1012 & Rabbit & $1: 240$ & Eugene Tech., NJ \\
\hline \multirow[t]{2}{*}{$\begin{array}{l}\text { VIP (porcine) } \\
\text { Vasoactive intestinal peptide }\end{array}$} & 7913 & Rabbit & $1: 200$ & $\begin{array}{l}\text { Dr. J. Walsh } \\
\quad \text { (Furness et al., 1981) }\end{array}$ \\
\hline & VIP FI/III & Rat & $1: 400$ & $\begin{array}{l}\text { Dr. R. Murphy } \\
\text { (Morris et al., 1985) }\end{array}$ \\
\hline
\end{tabular}

the paracervical ganglia that might innervate the pelvic vasculature. We also have examined the immunohistochemistry of the presynaptic fibers to elucidate the ncuronal pathways involved in autonomic control of the pelvic region.

\section{Materials and Methods}

Mature virgin female guinea pigs ( $350-450 \mathrm{gm}$ ) were killed by a blow to the head and rapid bleeding-out. The mesometrium in the angle between the caudal vesical, vaginal and uterine arteries, and the uterine cervix, was removed bilaterally, together with the arteries and the distal portions of the hypogastric nerve trunks (Fig. $1 A$ ). The mesometrium and blood vessels were pinned out in a petri dish containing ice-cold PBS to display the nerve trunks and ganglia in the paracervical region (Fig. $1 B$ ).

Catecholamine fluorescence. Some preparations of the paracervical ganglia were treated as whole-mounts for glyoxylic acid-induced catecholamine fluorescence (see Furness and Costa, 1975). In other preparations, the ganglia close to the uterine artery (Fig. $1 B$ ) were removed and fixed for $4-6 \mathrm{hr}$ at $2{ }^{\circ} \mathrm{C}$ in a phosphate-buffered solution containing $4 \%$ formaldehyde, $0.5 \%$ glutaraldehyde, $15 \%$ saturated picric acid, $2 \%$ glyoxylic acid, and $15 \%$ sucrose (Faglupagas; Imai et al., 1982). The ganglia were rinsed several times and stored in fresh fixative without picric acid (Faglugas) at $4^{\circ} \mathrm{C}$ for $1-7 \mathrm{~d}$. Ganglia were frozen and sectioned at $10-12 \mu \mathrm{m}$, dried onto chrome-alum-coated slides, incubated in a drop of Faglugas for $15-20 \mathrm{~min}$, and then heated at $100^{\circ} \mathrm{C}$ for $4 \mathrm{~min}$. All preparations were mounted in paraffin oil and viewed with a Leitz fluorescence microscope fitted with dichroic filter block $D$.

Amine loading. The paracervical ganglia and associated nerve trunks and blood vessels were removed from both sides of 2 animals, and were incubated in Krebs solution containing pargyline hydrochloride (Sigma; St. Louis, MO), $5 \times 10^{-6} \mathrm{M}$, for $15 \mathrm{~min}$ at $37^{\circ} \mathrm{C}$. The solution was bubbled with $95 \% \mathrm{O}_{2}: 5 \% \mathrm{CO}_{2}$. The ganglia were then incubated for 45 min with Krebs solution containing pargyline alone, pargyline + L-DOPA (L-DOPA methyl ester hydrochloride; Sigma), $2 \times 10^{-6} \mathbf{M}$, pargyline + dopamine hydrochloride (Sigma), $5 \times 10^{-6} \mathbf{M}$, or pargyline + noradrenaline hydrochloride (Sigma), $5 \times 10^{-6} \mathrm{M}$. This was followed by a further $30 \mathrm{~min}$ incubation in Krebs solution alone. Ganglia were then fixed in Faglugas and sectioned as described above, or treated as whole-mounts with glyoxylic acid.

Immunohistochemistry. Ganglia were fixed in phosphate-buffered picric acid $\left(15 \%\right.$ of saturated solution) and formaldehyde $(4 \%)$ at $4^{\circ} \mathrm{C}$ for 16-24 hr. Ganglia were then placed in dimethyl sulfoxide for $3 \times 10$ min, washed in PBS for $3 \times 10 \mathrm{~min}$, and stored in PBS containing $30 \%$ sucrose and $0.1 \%$ sodium azide. This fixation procedure has been found by this laboratory to satisfactorily demonstrate all of the peptides examined here (see Costa et al., 1986), although in some cases it is necessary to elevate peptide levels in the nerve cell bodies with colchicine treatment prior to fixation (see Discussion). This fixation procedure has also been used successfully to demonstrate tyrosine hydroxylase $(\mathrm{TH})$ and dopamine- $\beta$-hydroxylase (DBH) immunoreactivity (IR) in all peripheral neurons showing catecholamine fluorescence (e.g., Costa and Furness, 1984; Gibbins et al., 1986; Macrae et al., 1986; Morris et al., 1986a-d).

Cryostat sections were cut at $8 \mu \mathrm{m}$, and runs of serial sections were placed on adjacent chrome-alum-gelatin-coated slides. Sections were incubated for $30 \mathrm{~min}$ in PBS containing $10 \%$ sheep or human serum, and then simultaneously incubated with 2 of 16 primary antisera (see 
Table 2. Colocalization of immunoreactivity to DBH, NPY, TH, and VIP in serial sections

Nerve cell bodies in each ganglion with immunoreactivity to antisera (\%)

\begin{tabular}{clllllll}
\cline { 3 - 7 } Antiserum A/antiserum B & & $\mathrm{A}$ & $\mathrm{B}$ & $\mathrm{A}+\mathrm{B}$ & Neither & $\mathrm{A}$ & \multicolumn{1}{c}{ Botal } \\
\hline NPY E2210/TH 1012 & Median & 75 & 3 & 3 & 16 & 78 & 6 \\
$(n=12$ ganglia; 1282 cells $)$ & Range & $(36-88)$ & $(0-23)$ & $(0-15)$ & $(4-32)$ & & \\
NPY E2210/DBH 2D4 & Median & 11 & 12 & 60.5 & 12.5 & 71.5 & 72.5 \\
$(n=12$ ganglia; 943 cells) & Range & $(0-30)$ & $(0-58)$ & $(27-74)$ & $(0-32)$ & & \\
VIP F1/III/TH 1012 & Median & 64 & 8 & 0 & 29 & 64 & 8 \\
$(n=10$ ganglia; 964 cells $)$ & Range & $(25-88)$ & $(0-45)$ & $(0-3)$ & $(13-43)$ & & \\
VIP F1/III/DBH 2D4 & Median & 13.5 & 15.5 & 48 & 20.5 & 61.5 & 63.5 \\
$(n=10$ ganglia; 815 cells) & Range & $(0-50)$ & $(0-34)$ & $(35-80)$ & $(0-30)$ & & \\
NPY E2210/VIP 7913 & Median & 22.5 & 3.5 & 61 & 10.5 & 83.5 & 64.5 \\
$(n=10$ ganglia; 894 cells $)$ & Range & $(4-36)$ & $(0-10)$ & $(49-89)$ & $(0-31)$ & & \\
\hline
\end{tabular}

Table 1 for antiserum characteristics) for $16-20 \mathrm{hr}$ at room temperature. Twenty-four different combinations of primary antisera were used for double-labeling: anti-NPY E2210 together with anti-calcitonin generelated peptide (CGRP), anti-DBH, anti-dopa decarboxylase (DDC), anti-Dyn, anti-TH, or anti-VIP 7913; anti-VIP FI/III together with antiCGRP, anti-DBH, anti-DDC, anti-Dyn, or anti-TH; anti-SP NCl/34HL together with anti-Dyn, anti-NPY RMJ 263, anti-VIP 7913, or antiTH; anti-Enk NOCl together with anti-Dyn, anti-NPY RMJ 263, antiSP RMSP-1, anti-TH, or anti-VIP 7913; anti-Som S8 together with anti-DBH 2012, anti-NPY RMNJ 263, anti-TH, or anti-VIP 7913. These antisera were diluted (see Table 1) in hypertonic PBS $(1.7 \% \mathrm{NaCl}$; Grube, 1980). A different antiserum combinations was applied to each of 5-6 serial sections, and the sequence was then repcated across groups of 5-6 slides.

After primary antiserum incubation, the sections were washed with PBS and exposed to appropriate mixtures of fluorescein- and rhodamine-labeled secondary antibodies for $1 \mathrm{hr}$ at room temperature. When the primary antiserum mixture was anti-NPY E2210 raised in a sheep, with one of the antisera raised in rabbits, the secondary antibody mixture consisted of fluorescein isothiocyanate (FITC)-labeled swine anti-goat gamma globulin (Tago, Burlingame, CA, batch 010604) together with tetramethylrhodamine isothiocyanate (TRITC)-labeled swine anti-rabbit gamma globulin (Dako, Copenhagen, Denmark, batch 034A), each diluted 1:80 with hypertonic PBS. When anti-VIP FI/III or anti-SP $\mathrm{NCl} / 34 \mathrm{HL}$ raised in rats was used in conjunction with an antiserum raised in a rabbit, the secondary antibodies were TRITC-labeled goat anti-rat gamma globulin (Cappel Lab, Cochranville, PA, batch 21275 diluted 1:80 in PBS) and FITC-labeled sheep anti-rabbit gamma globulin (Wellcome Diagnostics, Roseberry, Australia, batch K890510 diluted 1:80). When anti-Enk NOCl or anti-Som S8 raised in mice was used with a rabbit primary antiserum, FITC-labeled goat anti-mouse gamma globulin (Tago, batch 504304) and TRITC-labeled goat antirabbit gamma globulin (Cappel, batch 22141) were used at a dilution of 1:160. Control tests indicated that with these batches of secondary antibodies there was no inappropriate binding of secondary antibodies to one another or to the inappropriate primary antiserum (see Costa et al., 1986).

Some sections were incubated simultaneously with 3 primary antisera raised in rabbits: anti-DBH 2012, anti-NPY RMJ 263, and anti-Som $18 \mathrm{~J} 22$. After incubation for $16 \mathrm{hr}$, sections were washed in PBS $(3 \times$ $10 \mathrm{~min}$ ) and cxposed to FITC-labclcd shecp anti-rabbit gamma globulin (Wellcome, batch K889820, diluted 1:100 in PBS) for $1 \mathrm{hr}$.

Sections were washed in PBS for $3 \times 10 \mathrm{~min}$, mounted in carbonatebuffered glycerol ( $\mathrm{pH} 8.6$ ), and viewed with a Leitz fluorescence microscope fitted with L3 and N2 dichroic filter blocks, which allow selective viewing of fluorescein and rhodamine fluorescence, respectively.

Colchicine treatment. Paracervical ganglia and associated nerve trunks were pinned to strips of autoclaved balsa wood and incubated for 8-24 hr at $37^{\circ} \mathrm{C}$ in $\mathrm{N} 2$ defined culture medium (Bottenstein and Sato, 1979) containing $10^{-4} \mathrm{M}$ colchicine (Sigma) and bubbled with medical grade air containing $5 \% \mathrm{CO}_{2}$. Ganglia were rinsed several times in PBS, and fixed and processed for immunohistochemistry as described above.
Absorption tests. Absorption tests were carried out on colchicinetreated ganglia incubated with one of the 5 double-labeling combinations of antisera listed in Table 2. The mixtures of anti-NPY E2210 with anti-DBH, anti-TH, or anti-VIP 7913 were preincubated with NPY (Peninsula, Belmont, CA), $10^{-4}-10^{-6} \mathrm{M}$, and mixtures of anti-VIP FI/ III with anti-DBH or anti-TH, and of anti-VIP 7913 with anti-NPY 2210 were preincubated with VIP (Peninsula), $10^{-4}-10^{-6} \mathbf{M}$, for $24 \mathrm{hr}$ at $4^{\circ} \mathrm{C}$ before application to sections for $16-20 \mathrm{hr}$, as above. All NPY-IR was abolished after preincubation of the primary antiserum mixtures with NPY, $10^{-6} \mathrm{M}$, while IR to DBH, TH, or VIP was unaffected. VIPIR was reduced after preincubation of primary antisera with $10^{-6} \mathrm{M}$, and was abolished by $10^{-5} \mathrm{M}$ VIP, while DBH-, NPY-, and TH-IR were unaffected.

Absorption tests for Dyn-, Enk-, Som-, and SP-like immunoreactivities were carried out on sections single-labeled with primary antiserum that had been equilibrated at $4^{\circ} \mathrm{C}$ for $24 \mathrm{hr}$ with a range of concentrations of synthetic peptides. Dyn-IR was abolished after preincubation of antiDyn Paul with Dyn 1-13 (Peninsula) at $10^{-6} \mathrm{M}$, but was unaffected after preincubation of anti-Dyn Paul with Leu-Enk (Sigma) at $10^{-4} \mathrm{M}$. EnkIR was reduced in intensity after preincubation of anti-Enk NOCl with Leu- or Met-Enk (Sigma) at $10^{-4} \mathrm{M}$, and was abolished after preincubation with Leu- or Met-Enk at $10^{-3} \mathrm{M}$ (see also Cuello et al., 1984). Som-IR, demonstrated by anti-Som S8 or anti-Som 18J22, was abolished after preincubation of each antiserum with Som 1-14 (Peninsula) at $10^{-6} \mathrm{M}$. All SP-IR was abolished after preincubation of anti-SP NCl$/$ $34 \mathrm{HL}$ with SP (Sigma) at $10^{-6} \mathrm{M}$.

\section{Results}

\section{General arrangement of paracervical ganglia}

The paracervical ganglia lay bilaterally at the caudal ends of the hypogastric nerve trunks, in the mesometrium between the uterine, vaginal, and caudal vesical arteries at the level of the junction between the uterine cervix and vagina (Fig. 1). Dissection of this region unilaterally and removal of the associated fat under a dissecting microscope revealed between 6 and 10 ganglia of varying sizes among a plexus of nerve trunks (cf. Thorbert et al., 1977). Small nerve trunks leaving some of the ganglia were observed traveling in both directions along the uterine artery and along the vaginal arteries (Fig. 1B). Larger nerve trunks followed the caudal vesicle artery and then traveled caudally along the lateral margin of the vagina to connect the paracervical ganglia with the posterior pelvic ganglia.

Although the absolute number and position of the paracervical ganglia varied between animals and even between sides of the same animal, it was usually possible to distinguish 5 or 6 main ganglia, close to the uterine artery, that could supply axons to the nerve trunks coursing to the artery (Figs. $1 B, 2$ ). The present study was restricted to these 5 or 6 ganglia: the ganglia 

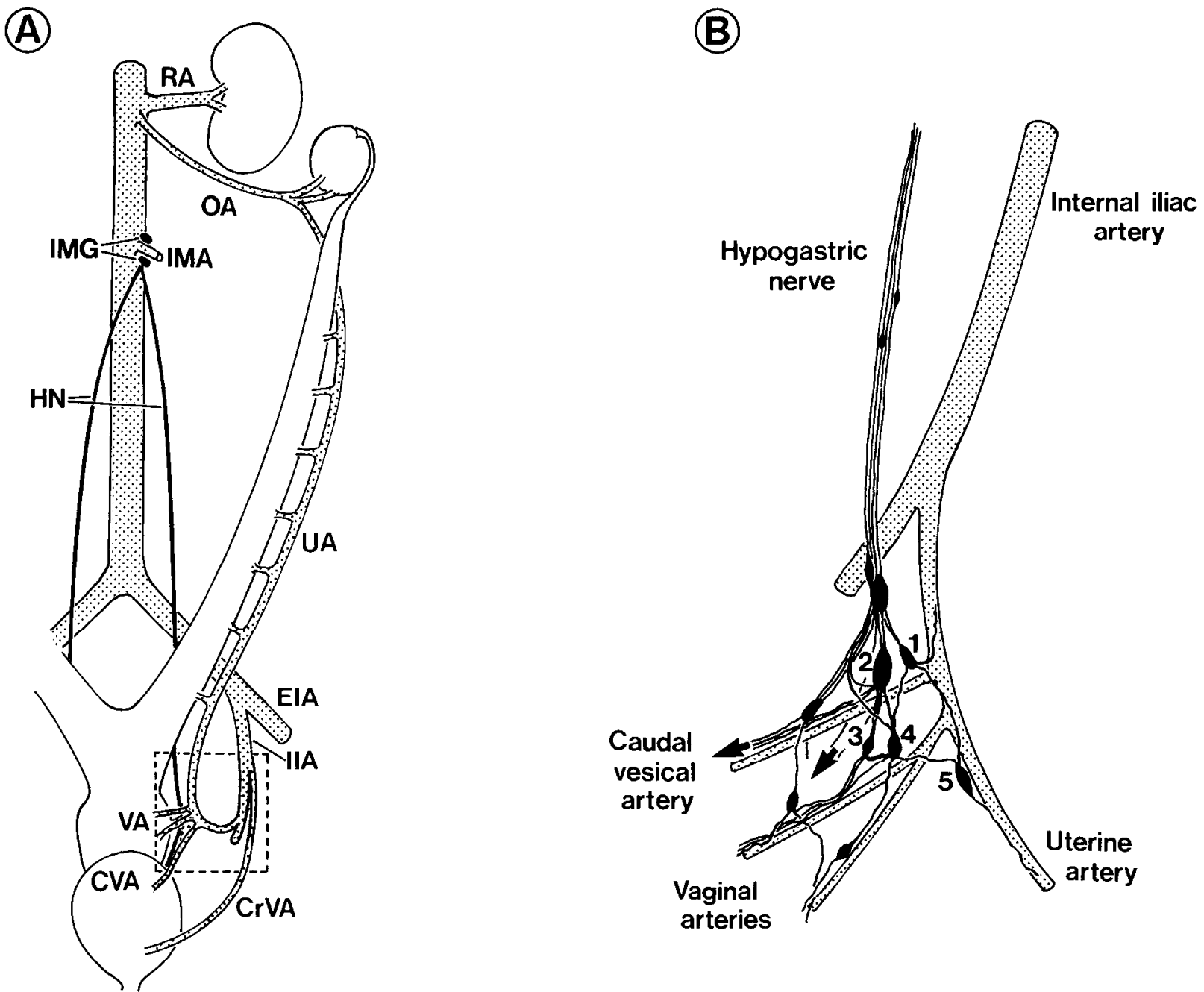

Figure 1. A, Diagram showing location of left paracervical ganglia (in boxed area) at distal end of hypogastric nerve trunk ( $H N)$, in the region of the caudal vesical artery $(C V A)$ and the vaginal arteries $(V A)$. $R A$, renal artery; $O A$, ovarian artery; $I M A$, inferior mesenteric artery; $I M G$, inferior mesenteric ganglia; $U A$, uterine artery; $E I A$, external iliac artery; $I I A$, internal iliac artery; $C r V A$, cranial vesicle artery. $B$, Diagram showing arrangement of left paracervical ganglia after lateral and caudal reflection of the uterine artery. Ganglia numbered $1-5$ were examined in this study. Arrows designate nerve trunks that connect with the posterior pelvic ganglia.

that lay along the main hypogastric nerve trunk, and more distally along the nerve trunks connecting with the posterior pelvic ganglia, have not been examined here. It is interesting to note that the paracervical ganglia in cats, rabbits, and humans are also arranged in diffuse clusters (Owman and Sjöberg, 1966; Owman et al., 1967; Rosengren and Sjöberg, 1967), and hence the existence bilaterally of a discrete paracervical (Frankenhäuser's) ganglion in rats (e.g., Kanerva, 1972) seems to be unusual.

\section{Neurons with catecholamine fluorescence}

After treatment of whole-mounts of the paracervical ganglia and associated nerve trunks with glyoxylic acid, it was apparent that many of the macroscopically identifiable ganglia were composed of accumulations of several microganglia containing neurons, extraadrenal chromaffin cells, and axon bundles with catecholamine fluorescence. Most, but not all, ganglia contained nerve cell bodies with catecholamine fluorescence (Fig. 2). The number of fluorescent neurons varied between ganglia, and often they were clumped eccentrically within individual ganglia. Clusters of small (5-10- $\mu \mathrm{m}$-diameter), intensely fluorescent extraadrenal chromaffin cells (SIF cells) were prominent along the nerve trunks, and were often associated with ganglia (Fig. 2). Some of these chromaffin cells had processes that could be followed for up to $200 \mu \mathrm{m}$. Fluorescent axons were present in the branches of the hypogastric nerve and in most nerve trunks passing between the paracervical ganglia. Several bundles of fluorescent axons coursed from the ganglia to the uterine artery.

Sections through ganglia treated with Faglupagas confirmed that the proportion of nerve cell bodies with catecholamine fluorescence was highly variable between ganglia, and that the fluorescent neurons were often clumped together. The fluorescent nerve cell bodies were irregular in shape, with many short processes, and were approximately $30-40 \mu \mathrm{m}$ long and $20-25$ $\mu \mathrm{m}$ wide. Clusters of extraadrenal chromaffin cells were often prominent near the periphery of the ganglia (Figs. 3, 4). Nonvaricose fluorescent axons and processes were seen in the vicinity of fluorescent nerve cells and chromaffin cells, but no varicose fluorescent axons were present in the ganglia (cf. Yokota and Burnstock, 1983).

Seven ganglia were sectioned serially, and the total number 


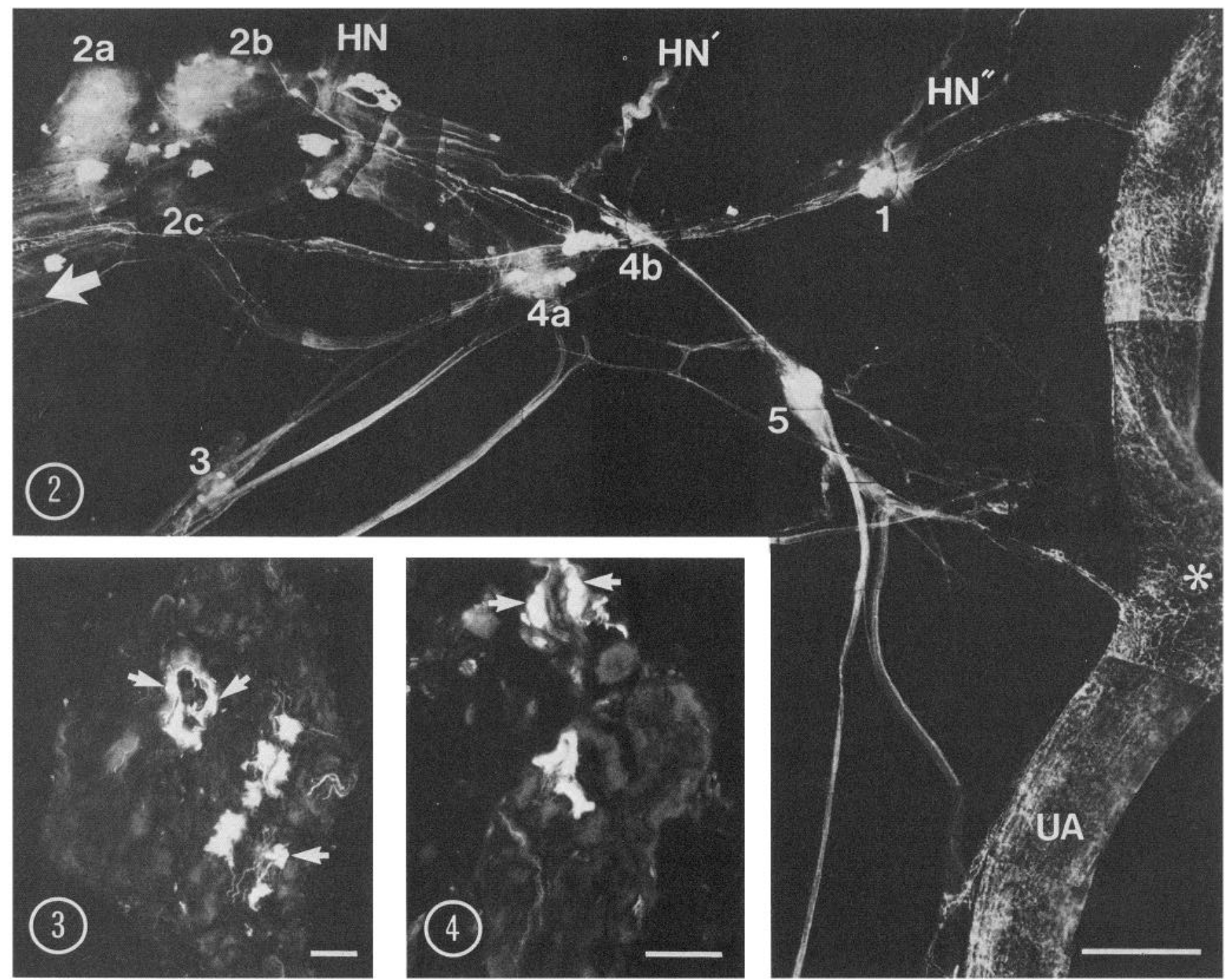

Figures 2-4. Figure 2, Photomontage of whole-mount of paracervical ganglia and uterine artery treated with glyoxylic acid for demonstration of catecholamine fluorescence. Asterisk marks origin of caudal vesical artery and vaginal arteries, which have been reflected laterally. Five main ganglia are present (cf. Fig. $1 B$ ) at the distal ends of branches of the hypogastric nerve trunks $\left(H N, H N^{\prime}, H N^{\prime \prime}\right)$, some of which can be seen microscopically to be composed of several small ganglia (ganglion 2,4$)$. Some ganglia $(2 c, 3)$ do not contain fluorescent nerve cell bodies. Clusters of small, intensely fluorescent chromaffin cells are apparent near some ganglia and along some nerve trunks. Arrow designates nerve trunk that connects with posterior pelvic ganglia. Scale bar, $500 \mu \mathrm{m}$. Figures 3 and 4, Sections through paracervical ganglia treated with Faglupagas for demonstration of catecholamines. A small proportion of neurons show catecholamine fluorescence. Groups of intensely fluorescent chromaffin cells (arrows) are prominent within (Fig. 3), or adjacent to (Fig. 4), the ganglia. Scale bars, $50 \mu \mathrm{m}$.

of neurons with and without catecholamine fluorescence was determined in alternate sections throughout the ganglia $(n=$ 1219 cells). The percentage of total neurons per ganglion showing catecholamine fluorescence ranged from 2 to $18 \%$, the median value being $6 \%$.

Paracervical ganglia incubated with pargyline alone, or with pargyline and L-DOPA, dopamine, or noradrenaline before $\mathrm{Fa}$ glupagas fixation, were sectioned, and the proportion of total neurons with catecholamine fluorescence was estimated. Although the background fluorescence of the connective tissue was higher in all incubated ganglia than in unincubated ganglia, the number of neurons showing catecholamine fluorescence did not seem to be increased by incubation with any of the amines. No ganglia appeared to contain more than $20 \%$ fluorescent neurons, and in most ganglia the percentage was estimated to be less than $10 \%$. No fluorescent varicose axons were detected in the incubated ganglia.

\section{Immunohistochemistry of nerve cell bodies}

Nerve cell bodies with immunoreactivity (IR) to TH, DBH, NPY, VIP, or Som were detected in most paracervical ganglia. The neurons were predominantly ovoid, 30-40 $\mu \mathrm{m}$ long and 15-20 $\mu \mathrm{m}$ wide, often with many short processes. Many nerve cell profiles were binucleate (cf. Yokota and Burnstock, 1983; Figs. 6, 9). The intensity of the TH-IR was consistently strong, but the IR to the peptides was variable, and was usually enhanced by colchicine treatment. Ganglia from some animals contained cell bodies with moderate to dim Dyn-IR, while no Dyn-IR was detected in ganglia from other animals. Dyn-IR cell bodies were always detected in colchicine-treated ganglia, although the intensity of the IR was still variable. No nerve cell bodies with IR to SP, Enk, or CGRP were detected in untreated or colchicine-treated ganglia.

All extraadrenal chromaffin cells (5-10 $\mu$ m diameter) within 

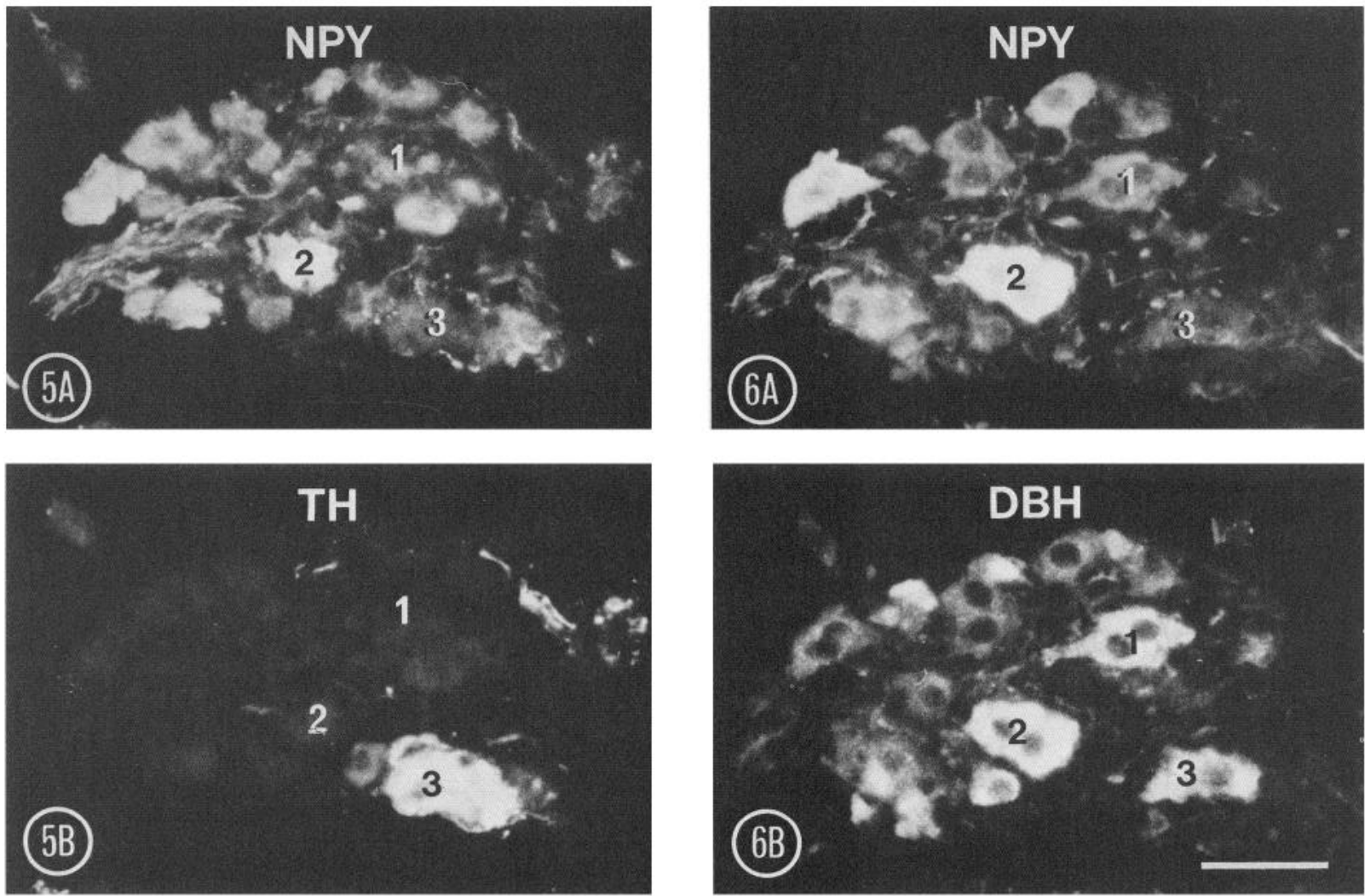

Figures 5-8. Figure 5, Section of ganglion double-labeled to demonstrate NPY-IR $(A)$ and TH-IR $(B)$. Most neurons with NPY-IR do not show TH-IR (cells 1,2 ). One neuron with TH-IR (cell 3) does not show NPY-IR, although it is surrounded by varicose axons with NPY-IR. Figure 6, Section adjacent to that shown in Figure 5, double-labeled to show NPY-IR $(A)$ and DBH-IR $(B)$. Of the 3 cells visible in both Figure 5 and Figure 6 , cells 1 and 2 have NPY-IR and DBH-IR without TH-IR, and cell 3 has DBH-IR and TH-IR without NPY-IR. Scale bar, $50 \mu$ m. Figure 7 , Section through small ganglion double-labeled to show VIP-IR $(A)$ and TH-IR $(B)$. No neurons with VIP-IR have TH-IR. Axons with intense TH-

the ganglia showed TH-IR and DBH-IR, and some also had NPY-IR or Dyn-IR.

Serial sections of both untreated and colchicine-treated ganglia were double-labeled with one of 5 combinations of antisera (see Table 2) to examine the relationships between nerve cell bodies with IR to catecholamine-synthesizing enzymes and cell bodies with IR to NPY or VIP. All nerve cell bodies in each profile were scored for the presence of IR to one, both, or neither antigen. Ganglia not treated with colchicine that showed dim IR were not included in this analysis. The percentages of total neurons per ganglion with IR to each of these antigens were quite variable between ganglia, but as the ranges of percentages of these cells were similar in untreated and colchicine-treated ganglia, the values from all ganglia were pooled.

Six to nine percent (median values) of all neurons were $\mathrm{TH}$ IR, yet $57-73 \%$ of neurons showed DBH-IR when either antiserum 2D4 or 2012 was used (Tables 2, 3). In serial sections it could be seen that all TH-IR nerve cell bodies were DBH-IR, while many cells contained DBH-IR but not TH-IR (Figs. 58). Therefore, we examined 3 ganglia for the presence of IR to

Table 3. Colocalization of immunoreactivity to DBH, NPY, Som, TH, and VIP in serial sections

Nerve cell bodies in each ganglion with immunoreactivity to antisera (\%)

\begin{tabular}{|c|c|c|c|c|c|c|c|}
\hline Antiserum A/antiserum B & & A & B & $A+B$ & Neither & $\begin{array}{l}\text { Total } \\
\text { A }\end{array}$ & $\begin{array}{l}\text { Total } \\
\text { B }\end{array}$ \\
\hline $\begin{array}{l}\text { Som } \mathrm{S} 8 / \mathrm{TH} 1012 \\
\quad(n=12 \text { ganglia; } 1278 \text { cells })\end{array}$ & $\begin{array}{l}\text { Median } \\
\text { Range }\end{array}$ & $\begin{array}{l}48 \\
(17-64)\end{array}$ & $\begin{array}{l}8.5 \\
(1-28)\end{array}$ & $\begin{array}{l}0.5 \\
(0-5)\end{array}$ & $\begin{array}{l}38.5 \\
(8-61)\end{array}$ & 48.5 & 9 \\
\hline $\begin{array}{l}\text { Som S8/DBH } 2012 \\
\quad(n=12 \text { ganglia; } 1272 \text { cells })\end{array}$ & $\begin{array}{l}\text { Median } \\
\text { Range }\end{array}$ & $\begin{array}{l}33 \\
(0-45)\end{array}$ & $\begin{array}{l}37 \\
(25-56)\end{array}$ & $\begin{array}{l}20 \\
(11-31)\end{array}$ & $\begin{array}{l}14.5 \\
(3-26)\end{array}$ & 53 & 57 \\
\hline $\begin{array}{l}\text { Som S8/NPY RMJ } 263 \\
\quad(n=12 \text { ganglia; } 1752 \text { cells })\end{array}$ & $\begin{array}{l}\text { Median } \\
\text { Range }\end{array}$ & $\begin{array}{l}19.5 \\
(1-31)\end{array}$ & $\begin{array}{l}39 \\
(29-64)\end{array}$ & $\begin{array}{l}33 \\
(11-61)\end{array}$ & $\begin{array}{l}8.5 \\
(3-22)\end{array}$ & 52.5 & 72 \\
\hline $\begin{array}{l}\text { Som S8/VIP } 7913 \\
\qquad(n=12 \text { ganglia; } 1483 \text { cells })\end{array}$ & $\begin{array}{l}\text { Median } \\
\text { Range }\end{array}$ & $\begin{array}{l}21 \\
(3-34)\end{array}$ & $\begin{array}{l}45 \\
(30-75)\end{array}$ & $\begin{array}{l}32 \\
(8-56)\end{array}$ & $\begin{array}{l}11 \\
(0-22)\end{array}$ & 53 & 77 \\
\hline
\end{tabular}



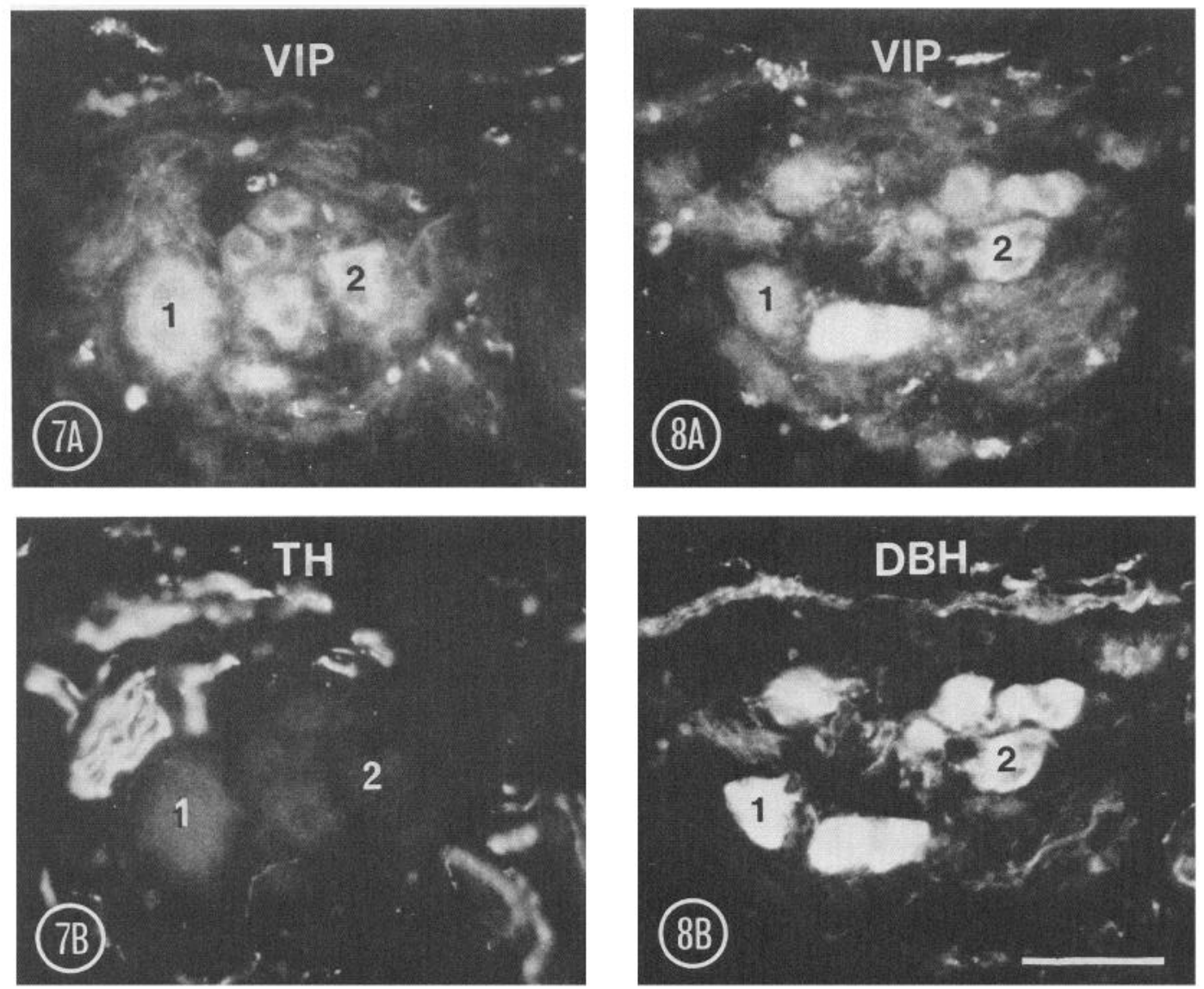

IR, but not VIP-IR, course through the ganglion. Figure 8, Section adjacent to that in Figure 7, double-labeled to demonstrate VIP-IR ( $A$ ) and DBH-IR (B). Many cells have both VIP-IR and DBH-IR (cells 1, 2), but do not have TH-IR. Scale bar, $50 \mu \mathrm{m}$.

another catecholamine-synthesizing enzyme, DDC (aromatic amino acid decarboxylase). A small proportion of neurons, estimated at less than $10 \%$, were DDC-IR. Examination of serial sections demonstrated that DDC-IR was associated only with neurons showing both TH- and DBH-IR, and was not associated with those DBH-IR neurons lacking TH-IR.

Between 72 and $84 \%$ (median values) of neurons showed NPY-IR, while $62-65 \%$ of neurons were VIP-IR. Double-labeling demonstrated that $61 \%$ of all neurons contained both NPY- and VIP-IR (Table 2; Fig. 9). Three percent of neurons had both NPY-IR and TH-IR, while only 2 out of 964 TH-IR neurons showed VIP-IR. In 9 out of 10 ganglia analyzed, no TH-IR nerve cell bodies were VIP-IR (Table 2; Fig. 7). Therefore, neurons containing both NPY- and VIP-IR did not have TH-IR. However, $48 \%$ of all neurons had both DBH- and VIPIR (Fig. 8), and $60 \%$ of neurons had both DBH- and NPY-IR (Fig. 6); thus there was a large number of neurons containing DBH-, NPY-, and VIP-IR without TH-IR. In addition, some DBH-IR neurons did not show NPY-IR ( $12 \%$ total neurons), or VIP-IR ( $16 \%$ total neurons).

About $50 \%$ of all nerve cell bodies showed Som-IR when either antiserum 18J22 or S8 was used (Figs. 10A, 11A, 12A). Serial sections double-labeled with anti-Som S8 together with anti-TH, anti-DBH 2012, anti-NPY RMJ 263, or anti-VIP 7913 revealed a complex pattern of coexistence of Som-IR with the other antigens. In 6 of 12 ganglia examined, a small proportion (1-5\%) of neurons had both Som-IR and TH-IR. In the other ganglia Som-IR and TH-IR were not found in the same neurons
(Fig. 12; see Table 3). Twenty percent of neurons had both SomIR and DBH-IR (Fig. 10), 33\% had both Som-IR and NPY-IR (Fig. 10), and 32\% had both Som-IR and VIP-IR (Table 3). Examination of the same neurons in serial sections indicated that probably all neurons with both Som-IR and NPY-IR also contained VIP-IR, while all neurons with both Som-IR and DBH-IR probably contained NPY-IR and VIP-IR. About $20 \%$ of all nerve cell bodies contained Som-IR, but did not show DBH-IR, NPY-IR, TH-IR, or VIP-IR.

Attempts to quantify the relationships between neurons with Dyn-IR and those with TH-, DBH-, NPY-, Som-, and VIP-IR were hampered by the great variation in intensity of the DynIR, even in colchicine-treated ganglia. Only a small sample of the total neurons labeled could be reliably scored for the presence or absence of Dyn-IR, so the number of neurons with DynIR in 3 ganglia was expressed as a percentage of the total number of neurons in the ganglia. About $45 \%$ of all neurons had DynIR. Examination of doubled-labeled serial sections indicated that nearly all Dyn-IR neurons had NPY-IR (Fig. 13) and VIPIR, and about half of the Dyn-IR neurons also had Som-IR (Fig. 14; Table 4). Although the appropriate primary antisera were not available to directly visualize the colocalization of Dyn-IR with IR to catecholamine-synthesizing enzymes, serial sections indicated that most neurons with Dyn-IR also had DBH-IR, while apparently none had TH-IR.

Combining the above information derived from double-labeling of serial sections, and the quantitative data from catecholamine histochemistry, one could distinguish as many as 11 

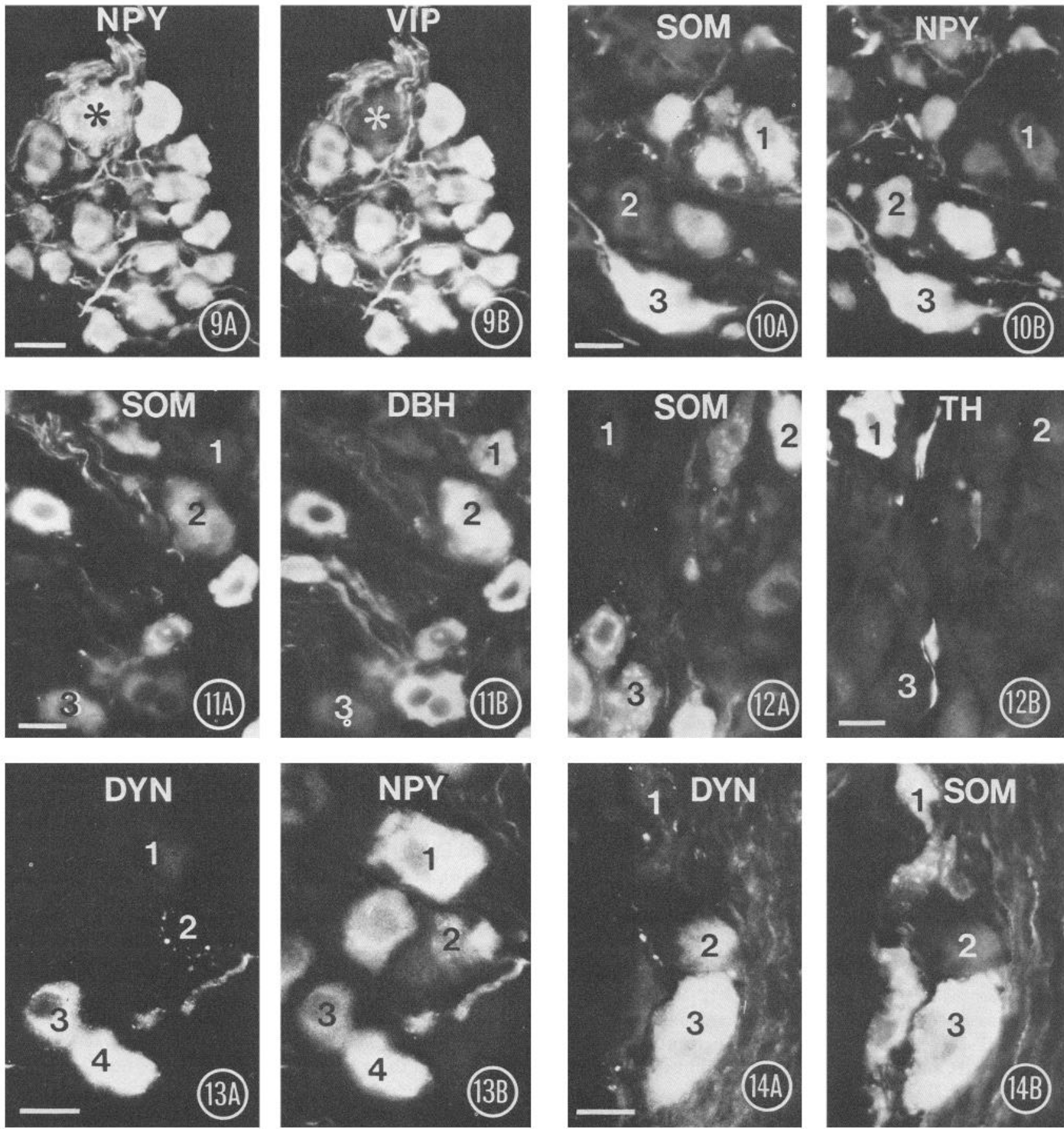

Figures 9-14. Sections double-labeled to demonstrate coexistence of IR to pairs of antigens in nerve cell bodies. Scale bars, $20 \mu \mathrm{m}$. Figure 9 , All neurons but one (asterisk) in this ganglion have both NPY-IR and VIP-IR. Figure 10, Some neurons have both Som-IR and NPY-IR (cell 3), while some have only Som (cell 1) or NPY-IR (cell 2). Figure 11, Some neurons with both Som-IR and DBH-IR (cell 2), and some with Som-IR alone (cell 3) or DBH-IR alone (cell 1). Figure 12, No neurons in this ganglion have both Som-IR and TH-IR. Figure 13, Some NPY-IR neurons have Dyn-IR (cells 3, 4) and some do not (cells 1, 2). One NPY-IR neuron (cell 2) has associated Dyn-IR nerve terminals. Figure 14, Dyn-IR and Som-IR coexist in one neuron (cell 3), while another has Dyn-IR alone (cell 2), and another Som-IR alone (cell 1).

classes of neurons in the paracervical ganglia (Table 5). Six to ten percent of all neurons contained noradrenaline, as well as the catecholamine-synthesizing enzymes TH and DBH (and DDC): Half of these neurons (3-5\%) contained NPY-IR, while the other half did not have immunoreactivity to any of the peptides examined here. As the number of nerve cell bodies with both TH-IR and Som-IR was so small (median value,
$0.5 \%$ ), it could not be determined from serial-section analysis whether or not these neurons also had NPY-IR.

Using the median values from Table 2, it can be argued that, as $57 \%$ of neurons had both NPY- and DBH-IR, but not THIR, $48 \%$ had VIP- and DBH-IR, but not TH-IR, and $61 \%$ had both NPY- and VIP-IR, then about $50 \%$ of all neurons contained NPY-, VIP-, and DBH-IR, but were not noradrenergic. 


\begin{tabular}{|c|c|c|c|c|c|c|}
\hline \multirow[b]{2}{*}{ Antiserum $\mathrm{A}$ /antiserum $\mathrm{B}$} & \multicolumn{6}{|c|}{$\begin{array}{l}\text { Total nerve cell bodies in } 3 \text { ganglia with immunore- } \\
\text { activity to antisera (\%) }\end{array}$} \\
\hline & A & B & $A+B$ & Neither & $\begin{array}{l}\text { Total } \\
\mathrm{A}\end{array}$ & $\begin{array}{l}\text { Total } \\
\text { B }\end{array}$ \\
\hline \multicolumn{7}{|l|}{ Dyn Paul/NPY E2210 } \\
\hline ( $n=3$ ganglia; 371 cells) & 2 & 30 & 47 & 21 & 49 & 77 \\
\hline \multicolumn{7}{|l|}{ Dyn Paul/VIP F1/III } \\
\hline ( $n=3$ ganglia; 439 cells) & 1 & 21 & 42 & 37 & 43 & 63 \\
\hline \multicolumn{7}{|l|}{ Dyn Paul/Som S8 } \\
\hline ( $n=3$ ganglia; 406 cells) & 15 & 31 & 24 & 30 & 39 & 55 \\
\hline
\end{tabular}

Probably most of these neurons also had Dyn-IR (Table 4), and half of them (20-25\%) also had Som-IR (Table 3). Data from Tables 3 and 4 indicate that, as $33 \%$ of neurons had Som-IR and NPY-IR, 32\% had Som-IR and VIP-IR, 20\% had Som-IR and DBH-IR, and $24 \%$ had Som-IR and Dyn-IR, then about $10 \%$ of neurons had NPY-/SOM-/VIP-IR without the other antigens. Combining this with the data in Table 2, it seems that small populations of neurons ( $5 \%$ total neurons) with $\mathrm{DBH}$ / NPY or NPY alone probably exist.

In order to determine whether or not all nerve cell bodies have been labeled by the antisera used in this study, sections from 3 ganglia were labeled simultaneously with antisera to DBH, NPY, and Som and visualized with a single fluorophore, which should label the major neuron populations (see Table 5). Of 1080 nerve cell bodies examined, only $5 \%$ were not labeled by any of these antisera. It is possible that this $5 \%$ of neurons may correspond to small numbers of neurons with VIP-IR alone (3.5\%; see Table 2) or with Dyn-IR alone (1-2\%; see Table 4), which are indicated by the median values. However, attempts to apply more than 3 primary antisera simultaneously did not produce immunoreactivity of sufficient intensity to clarify this issue. Thus, it can only be concluded that at least $95 \%$, and possibly all of paracervical neurons were labeled by the antigens used in this study.

It is apparent from examining the total median percentages of neurons with immunoreactivity to a particular antigen that, in general, the number of neurons labcled with different antisera combinations is quite consistent. The only major discrepancy

Table 5. Classes of nerve cell bodies in paracervical ganglia, deduced from median values in Tables 2-4

\begin{tabular}{lc} 
& $\begin{array}{l}\text { Total neurons } \\
(\%)\end{array}$ \\
\hline DBH/TH & $3-5$ \\
DBH/TH/NPY & $3-5$ \\
DBH/TH/Som/ \pm NPY & 0.5 \\
DBH/Dyn/NPY/VIP & $20-25$ \\
DBH/Dyn/NPY/Som/VIP & $20-25$ \\
NPY/Som/VIP & 10 \\
DBH/NPY & 5 \\
Dyn alone & $1-2$ \\
NPY alone & 5 \\
Som alone & $10-20$ \\
VIP alone & 3.5 \\
\hline
\end{tabular}

arising from using median values of labeled neurons to determine neuron populations is that Tables 3 and 4 indicate that about $20 \%$ of neurons have Som-IR alone, while Table 2 indicates that only $10-12 \%$ do not have NPY-IR or VIP-IR. Considering that the ganglia analyzed in Tables 2-4 were different, and that the range of values between ganglia was great, it seems likely that the percentage of neurons with Som-IR alone lies between 10 and $20 \%$.

\section{Immunohistochemistry of nerve terminals}

Varicose nerve fibers with immunoreactivity to CGRP, Dyn, Enk, NPY, Som, SP, or VIP were detected in the paracervical ganglia. The nerve terminals were divided into at least 6 classes, based on the type of association between the terminals and nerve cell bodies within the ganglia, the coexistence of neuropeptides within the terminals, and the immunohistochemical markers within the nerve cell bodies with which the terminals were associated (sce Fig. 23).

A small proportion of nerve cell bodies in most ganglia was surrounded by varicose fibers with NPY-IR alone. These cells always had DBH- (Fig. 6), TH- (Fig. 5) or DDC-IR, and sometimes had NPY-IR. In fact, almost every cell with TH-IR was surrounded by terminals with NPY-IR. Occasionally, varicose fibers with both NPY - and VIP-IR, or NPY- and Som-IR were seen. These were always associated, respectively, with cell bodies containing both NPY- and VIP-IR (Fig. 15), or NPY- and Som-IR.

Nerve terminals with SP-IR were prominent in all ganglia. Some of these werc varicose, with very intense SP-IR, and passed through the ganglia without making close associations with nerve cell bodies. These processes contained CGRP-IR (Fig. 16), and were often restricted to regions of the ganglia containing NPYor VIP-IR nerve cell bodies. The majority of nerve terminals with SP-IR did not contain CGRP-IR (Fig. 16), or any other antigen studied here. These varicose fibers formed dense baskets around most nerve cell bodies with Dyn-, NPY-, or VIP-IR (Fig. 17), and some, but not all, neurons with Som-IR (Fig. 19). The dense SP-IR baskets were never associated with TH-IR neurons (Fig. 18).

Dense baskets of varicose nerve fibers with intense Enk-IR were also prominent in all ganglia. These baskets were never found around cells that had SP-IR baskets, and were not associated with neurons with Dyn-, NPY-, VIP-, or TH-IR (Fig. 21 ); they were associated exclusively with Som-IR neurons (Fig. 22), although only about half of the Som-IR cells had associated Enk-IR baskets. Varicose fibers with dim Enk-IR were occasionally seen associated with neurons that were also surrounded 

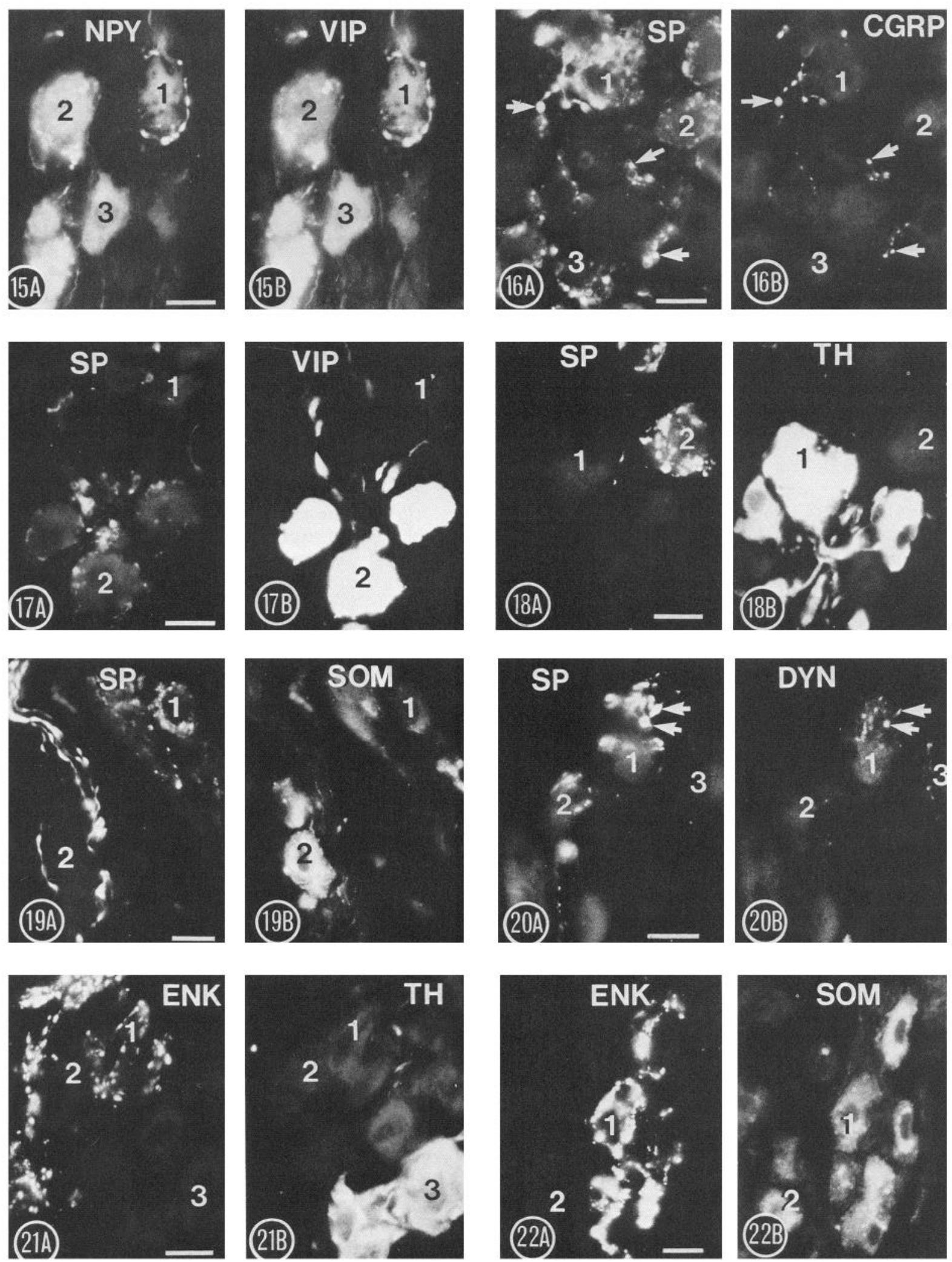

Figures 15-22. Sections double-labeled to show relationships between nerve fibers and nerve cell bodies. Scale bars, $20 \mu \mathrm{m}$. Figure 15, A small proportion of neurons with both NPY-IR and VIP-IR are surrounded by varicose fibers with NPY-IR and VIP-IR (cell 1 ). Figure 16, Some varicose axons have both SP-IR and CGRP-IR (arrows). Many nerve cell bodies (1-3) are surrounded by dense baskets of nerve terminals with SP-IR, but not CGRP-IR. Figure 17, SP-IR fibers surround neurons with VIP-IR (cell 2), but not neurons without VIP-IR (cell 1). Figure 18, Neurons with TH-IR (cell $I$ ) do not have associated fibers with SP-IR. Figure 19, Some neurons surrounded by SP-IR baskets do not have Som-IR (cell 1 ), and some Som-IR neurons (cell 2) have associated SP-IR axons. Figure 20, Some neurons (cell 1) are surrounded by nerve fibers with SP-IR, as well as nerve fibers with Dyn-IR. Some varicosities appear to contain both SP-IR and Dyn-IR (arrows). Other cells receive fibers with SP-IR alone (cell 2) or Dyn-IR alone (cell 3). Figure 21, Varicose fibers with Enk-IR are associated with cells without TH-IR (cells 2, 3). Figure 22, Enk-IR nerve fibers are associated only with Som-IR cells (cell 1), but some Som-IR cells (cell 2) do not have associated Enk-IR fibers. 
by NPY-IR varicosities. In a few varicosities, Enk-IR appeared to coexist with NPY-IR.

Varicose nerve fibers with Dyn-IR were detected in most ganglia, and were associated with some of the neurons with NPY-IR (Fig. 13) or VIP-IR. Consequently, some neurons were surrounded by SP-IR baskets, as well as by Dyn-IR processes. Most of these SP- or Dyn-IR varicosities were separate, although a few varicosities appeared to contain both SP- and Dyn-IR (Fig. 20). Other neurons were supplied by only SP-IR or DynIR processes (Fig. 20). Varicosities with dim Dyn-IR were sometimes associated with neurons that were also surrounded by NPY-IR processes. These neurons did not contain VIP-IR, but sometimes contained NPY-IR.

These findings demonstrate that at least 3 of the immunohistochemically distinct classes of nerve cell bodies in the paracervical ganglia were supplied by different immunohistochemical classes of nerve terminals (Fig. 23): (1) Almost all noradrenergic nerve cell bodies appeared to be surrounded by terminals with NPY-IR. A small proportion of these terminals contained Dyn-IR or Enk-IR, and some cells were surrounded by terminals with dim Dyn-IR or Enk-IR, which were separate from the NPY-IR terminals. (2) Most of the DBH/Dyn/NPY/ $\mathrm{VIP} /( \pm$ Som $)$ neurons were surrounded by dense baskets of varicose nerve fibers with SP-IR, and a subpopulation of these neurons (or neurons with $\mathrm{NPY} / \mathrm{VIP} /( \pm$ Som)) had associated terminals with Dyn-IR. (3) Dense baskets of terminals with bright Enk-IR seemed selectively to surround neurons that contained Som-IR alone. It is also likely that the rare fibers with NPY/Som/VIP supplied nerve cell bodies with NPY/Som/VIP, although the possibility cannot be excluded that these cell bodies may also have contained DBH- or Dyn-IR.

\section{Discussion}

\section{Noradrenergic neurons}

This study has demonstrated that only a small proportion of neurons in the guinea pig paracervical ganglia has the characteristics of noradrenergic neurons: less than $10 \%$ (median values) of nerve cell bodies showed catecholamine fluorescence and contained immunoreactivity to the catecholamine-synthesizing enzymes tyrosine hydroxylase (TH), dopa decarboxylase (DDC), and dopamine-B-hydroxylase (DBH). This proportion of noradrenergic neurons is somewhat less than that reported in paracervical ganglia of other species (e.g., rabbit, cat, human: Sjöberg, 1967; rat: Kanerva, 1972), where up to one-third of the nerve cell bodies showed catecholamine fluorescence. It is also interesting that in the much larger anterior pelvic ganglia of male guinea pigs, between one- and two-thirds of the nerve cell bodies are noradrenergic (Costa and Furness, 1973; Yokota and Burnstock, 1983; and M. Costa and J. B. Furness, personal communication).

\section{Non-noradrenergic neurons with $D B H-I R$}

About half of the nerve cell bodies in the paracervical ganglia had DBH-IR, but no other characteristics of noradrenergic neurons: They did not show native catecholamine fluorescence with the very sensitive glyoxylic acid technique (Howe et al., 1981; cf. Malmfors, 1965; Furness et al., 1986), did not take up exogenous catecholamines, did not have detectable TH- or DDC$\mathrm{IR}$, and did not produce and retain dopamine when supplied with the substrate for DDC, L-DOPA.

In the present study, it has not been detcrmincd whether the
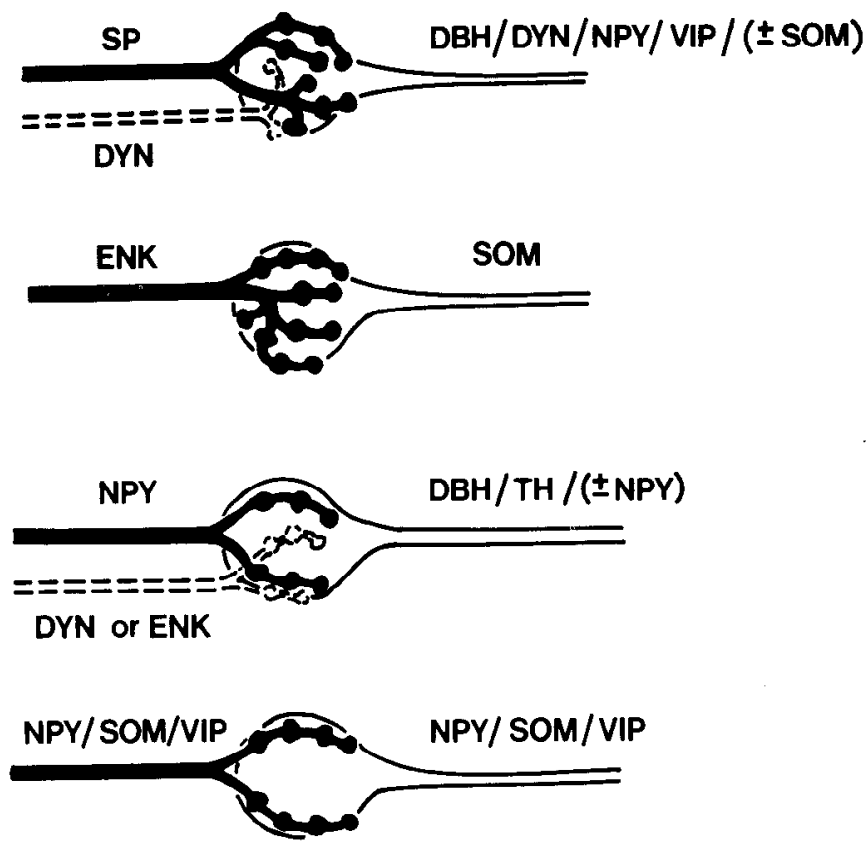

Figure 23. Summary diagram showing the main associations between immunohistochemically defined classes of nerve cell bodies and nerve fibers in paracervical ganglia. Dashed lines represent nerve fibers with dim IR that supply only a small proportion of neurons within each class.

DBH-IR in non-noradrenergic neurons represents the presence of the active enzyme. However, the DBH-IR was detected with 2 polyclonal antisera raised in different laboratories (see Table 1), one of which (2012) shows only an immunoreactive band corresponding to a subunit of $\mathrm{DBH}$ on an immunoblot against rat adrenal gland (characterized by Eugene Tech., NJ). Therefore, the antiserum recognizes authentic DBH, which presumably produces the DBH-IR in noradrenergic paracervical neurons, but it may also recognize a different substance in non-noradrenergic neurons that has an antigenic site or sites similar to DBH.

There have been many previous reports, from both functional and immunohistochemical studies, of catecholamine-synthesizing enzymes in neurons that do not normally synthesize catecholamines (e.g., Ehinger and Falck, 1970; Costa et al., 1976; Furness and Costa, 1978; Grzanna and Coyle, 1978; Ross et al., 1984; Björklund et al., 1985; Klemm et al., 1985; Teitelman et al., 1985; Park et al., 1986). Some of these neurons also have amine uptake and storage mechanisms, and the capability of turning on catecholamine synthesis in response to an appropriate stimulus (see Jonakait et al., 1984; Coulombe and Bronner-Fraser, 1986). Whether the DBH-IR paracervical ganglion cells might assume other properties of catecholamine neurons given the appropriate stimulus remains to be determined. On the other hand, it is possible that the neurons express the noradrenergic phenotype transiently during development, as occurs for some other neurons (Johnson et al., 1976; Patterson, 1978; Teitelman et al., 1978, 1981; Landis and Keefe, 1983; Potter et al., 1986), but subsequently lose all noradrenergic characteristics except DBH-IR.

Taken together, these studies emphasize that great caution must be used when applying antisera directed against one of the catecholamine-synthesizing enzymes as a specific marker for catccholamincrgic ncurons. It is cssential that other tcchniques, 
such as direct histochemical demonstration of catecholamines, or functional tests, be used in conjunction with immunohistochemistry of catecholamine-synthesizing enzymes (see also Grzanna and Coyle, 1978; Björklund et al., 1985; Klemm et al., 1985).

\section{Cholinergic neurons}

There is functional evidence that at least some of the nonnoradrenergic neurons in guinea pig paracervical ganglia provide cholinergic vasodilator innervation to the uterine artery (Bell, 1968, 1974). Although immunoreactivity to choline acetyltransferase has been used successfully in the central nervous system as a specific marker of cholinergic neurons, this methodology has not been successfully applied to peripheral autonomic neurons on a routine basis. Therefore, in the present study it was not possible to determine the percentage of paracervical neurons that were cholinergic.

\section{Colocalization of peptides in nerve cell bodies}

The present study has demonstrated that $90-95 \%$ of paracervical nerve cell bodies contain one or more neuropeptides. Furthermorc, the quantification of labcled ncurons using multiple combinations of primary antisera has allowed us to demonstrate up to 3 populations of noradrenergic neurons and 8 populations of non-noradrenergic neurons containing different single peptides, or different peptide combinations (Table 5). Such a classification of neurons would not have been possible with singlelabeling immunofluorescence techniques. The demonstration of populations of non-noradrenergic neurons that have 2 or 3 neuropeptides in common, but that differ by one or 2 other antigens (e.g., DBH/Dyn/NPY/VIP; DBH/Dyn/NPY/Som/VIP; NPY/ Som/VIP), raises the question as to whether these neurons belong to a single population in which each peptide may vary in concentration and thus may fall below the level of histochemical detection. The intensity of immunoreactivity, particularly to dynorphin, varied greatly between ganglia obtained from different animals, which may well represent a real variation in peptide levels. However, the proportions of neurons with IR to neuropeptides other than dynorphin did not differ significantly between untreated ganglia and ganglia incubated for up to 24 $\mathrm{hr}$ in culture medium containing colchicine. Therefore, the neurons distinguished here by different combinations of peptides are likely to represent separate populations of neurons. It is possible that long-term factors, such as hormonal influences, may alter the proportions of these populations by inducing changes in peptide synthesis, cleavage from precursors, or storage.

The functional significance of multiple peptides' being present in the same neurons, and of the same peptide's (e.g., NPY) occurring in several different classes of neurons is not at all clear. The roles of single neuropeptides in peripheral autonomic neurotransmission are being delineated gradually. It appears that VIP and NPY contained in perivascular axons, for example, interact with the nonpeptide transmitters acetylcholine and noradrenaline, respectively, to affect vascular tone (Lundberg, 1981; Lundberg et al., 1981, 1982a, b, 1984, 1985). If all of the peptides contained in a single neuron are released from its peripheral end, the interactions between these peptides, and between peptides and any nonpeptide transmitters, will be complex indeed. Thus, the actions of a particular peptide when released from different classes of neurons may be different, depending upon the types and amounts of coreleased substances.

\section{Connectivity of neuronal populations}

The subclassification of both noradrenergic and non-noradrenergic paracervical neurons on the basis of immunoreactivity to particular combinations of neuropeptides and enzymes is likely to relate to the distributions of their axons to peripheral target tissues. This type of neuronal coding has been described previously in submucous ganglia (Furness et al., 1984; Furness and Costa, 1987), coeliac ganglion (Costa and Furness, 1984; Lindh et al., 1986; Macrae et al., 1986) and dorsal root ganglia (Gibbins et al., 1987a) of guinea pigs. We have not yet identified the peripheral targets of all the paracervical neurons, although some of the non-noradrenergic neurons with IR to DBH/Dyn/NPY/ $\operatorname{VIP}( \pm$ Som $)$ project to the uterine artery (Morris et al., 1985, 1986a, and J. Morris, unpublished observations). On the other hand, neurons with Som-IR alone or Som/TH-IR do not project to the uterine artery, but have been found in the musculature of the uterine horn (J. Morris and I. Gibbins, unpublished observations). Therefore, some target specificity of paracervical neurons has been demonstrated, but the occurrence of at least 2 classes of non-noradrenergic axons in the uterine artery (DBH/ Dyn/NPY/VIP and DBH/Dyn/NPY/Som/VIP) indicates that there is not necessarily a one-to-one relationship between each class of neurons and each target tissue.

Within the guinea pig paracervical ganglia there are consistent associations between immunohistochemically identified nerve terminals and populations of postganglionic nerve cell bodies (see Fig. 23). For example, we now know that the previously described nerve terminals containing Enk-IR (see Alm et al., 1981; Schultzberg et al., 1983) selectively surround those nerve cell bodies containing Som-IR alone, and that the dense baskets of SP-IR fibers (e.g., Dalsgaard et al., 1983) supply the DBH/ Dyn/NPY/VIP $( \pm$ Som $)$ nerve cell bodies. It should be noted that these SP-IR fibers, which do not contain CGRP-IR, are resistant to capsaicin treatment (Dalsgaard et al., 1983; Gibbins et al., $1987 \mathrm{a}$ ), and are unlikely to be sensory. Similar close associations between populations of immunohistochemically identified classes of neurons have been described previously in guinea pig coeliac ganglion (Schultzberg et al., 1983; Lindh et al., 1986; Macrae et al., 1986), cat prevertebral and paravertebral sympathetic ganglia (Heym et al., 1984), and paravertebral sympathetic ganglia of toads (Morris et al., 1986b) and humans (Gibbins et al., 1986).

Taken together, these specific associations between immunohistochemically defined populations of neurons and their target tissues, and between pre- and postganglionic neurons, indicate that immunohistochemical coding of neuronal pathways is likely to be correlated with the function of each pathway in the autonomic control of peripheral tissues (see also Lindh et al., 1986; Furness et al., 1987).

\section{References}

Alm, P., J. Alumets, R. Håkanson, G. Helm, Ch. Owman, N.-O. Sjöberg, and F. Suridler (1980a) Vasoactive intestinal polypeptide nerves in the human female genital tract. Am. J. Obstet. Gynecol. 136: 349351 .

Alm, P., J. Alumets, R. Håkanson, Ch. Owman, N.-O. Sjöberg, F. Sundler, and B. Walles (1980b) Origin and distribution of VIPnerves in the genito-urinary tract. Cell Tissue Res. 205: 337-347.

Alm, P., J. Alumets, R. Håkanson, Ch. Owman, N.-O. Sjöberg, M. Stjernqvist, and F. Sundler (1981) Enkephalin-immunoreactive nerve fibres in the feline genito-urinary tract. Histochemistry 72: 351-355.

Bell, C. (1968) Dual vasoconstrictor and vasodilator innervation of the uterine arterial supply in the guinea-pig. Circ. Res. 23: 279-289. 
Bell, C. (1974) Selective cholinergic denervation of the uterine artery in guinea-pig. Experientia 30: 257-258.

Björklund, H., T. Hökfelt, M. Goldstein, L. Terenius, and L. Olson (1985) Appearance of the noradrenergic markers tyrosine hydroxylase and neuropeptide $\mathrm{Y}$ in cholinergic nerves of the iris following sympathectomy. J. Neurosci. 5: 1633-1643.

Blessing, W. W., P. R. C. Howe, T. H. Joh, J. R. Oliver, and J. O. Willoughby (1986) Distribution of tyrosine hydroxylase and neuropeptide $Y$-like immunoreactive neurons in rabbit medulla oblongata, with attention to colocalization studies, presumptive adrenaline-synthesizing perikarya, and vagal preganglionic cells. J. Comp. Neurol. 248: 285-300.

Bottenstein, J. E., and G. H. Sato (1979) Growth of a rat neuroblastoma cell line in serum free supplemented medium. Proc. Natl. Acad. Sci. USA 76: 514-517.

Buchan, A. M. J., L. K. J. Sikora, J. G. Levey, C. H. S. McIntosh, I. Dyck, and J. C. Brown (1985) An immunocytochemical investigation with monoclonal antibodies to somatostatin. Histochemistry 83: $175-180$.

Costa, M., and J. B. Furness (1973) Observations on the anatomy and amine histochemistry of the nerves and ganglia which supply the pelvic viscera and on the associated chromaffin tissue in the guineapig. Z. Anat. Ent. Ges. 140: 85-108.

Costa, M., and J. B. Furness (1984) Somatostatin is present in a subpopulation of noradrenergic nerve fibres supplying the intestine. Neuroscience 13: 911-920.

Costa, M., J. B. Furness, and J. R. McLean (1976) The presence of aromatic L-amino acid decarboxylase in certain intestinal cells. Histochemistry 48: 129-143.

Costa, M., J. B. Furness, and I. L. Gibbins (1986) Chemical coding of enteric neurons. In Progress in Brain Research, Vol. 68, T. Hökfelt, K. Fuxe, and P. Pernow, eds., pp. 217-239, Elsevier, Amsterdam.

Coulombe, J. N., and M. Bronner-Fraser (1986) Cholinergic neurones acquire adrenergic transmitters when transplanted into an embryo. Nature 324: 569-572.

Cuello, A. C., G. Galfre, and C. Milstein (1979) Detection of substance $P$ in the central nervous system by a monoclonal antibody. Proc. Natl. Acad. Sci. USA 76: 3532-3536.

Cucllo, A. C., C. Milstcin, R. Couture, B. Wright, J. V. Priestly, and J. Jarvis (1984) Characterization and immunochemical application of monoclonal antibodies against enkephalins. J. Histochem. Cytochem. 32: $947-957$.

Dalsgaard. C.-J., S. R. Vincent, M. Schultzberg, T. Hökfelt, L.-G. Elfvin, L. Terenius, and G. J. Dockray (1983) Capsaicin-induced depletion of substance P-like immunoreactivity in guinea-pig sympathetic ganglia. J. Auton. Nerv. Syst. 9: 595-606.

Ehinger, B., and B. Falck (1970) Uptake of some catecholamines and their precursors into ncurons of the rat ciliary ganglion. Acta Physiol. Scand. 78: 132-141.

Furness, J. B., and M. Costa (1975) The use of glyoxylic acid for the fluorescence histochemical localization of catecholamines and 5-hydroxytryptamine in whole mount preparations. Histochemistry 41 . 335-352.

Furness, J. B., and M. Costa (1978) Distribution of intrinsic nerve cell bodies and axons which take up aromatic amines and their precursors in the small intestine of the guinea-pig. Cell Tissue Res. 188: 527543.

Furness, J. B., and M. Costa (1987) The Enteric Nervous System. Churchill Livingstone, Edinburgh.

Furness, J. B., M. Costa, and J. H. Walsh (1981) Evidence for and significance of the projections of VIP neurons from the myenteric plexus to the taenia coli in the guinea-pig. Gastroenterology 80:15571561 .

Furness, J. B., M. Costa, and J. R. Kcast (1984) Choline acetyltransferase and peptide immunoreactivity of submucous neurons in the small intestine of the guinea-pig. Cell Tissue Res. 237: 328-336.

Furness, J. B., M. Costa, and I. J. Llewellyn-Smith (1987) Localization of monoamines by aldehyde-induced fluorescence in the peripheral nervous system. In Monoaminergic Neurons: Light Microscopy and Ultrastructure, H. W. M. Steinbusch, cd., pp. 1-26, Wiley, Chichester, UK.

Furness, J. B., M. Costa, J. L. Morris, and I. L. Gibbins (1987) Novel neurotransmitters and the chemical coding of neurons. Adv. Physiol. Res. (in press).

Gibbins, I. L.. D. Wattchow, J. Walsh, P. Dupont, M. Costa, and J. Furness (1986) Specific connections between immunohistochemi- cally identified classes of preganglionic and postganglionic neurons in human lumbar sympathetic chain ganglia. Neurosci. Lett. (Suppl.) 23: $\mathrm{S49}$

Gibbins, I. L., J. B. Furness, and M. Costa (1987a) Pathway-specific patterns of co-existence of substance $P$, calcitonin gene-related peptide, cholecystokinin and dynorphin in dorsal root ganglion neurons of the guinea-pig. Cell Tissue Res. 248: 417-437.

Gibbins, I. L., J. L. Morris, J. B. Furness, and M. Costa (1987b) Chemical coding of autonomic ncurons. Exp. Brain Res. (in press).

Grube, D. (1980) Immunoreactivities of gastrin (G-) cells. II. Nonspecific binding of immunoglobins to $G$-cells by ionic interactions. Histochemistry $66: 149-167$.

Grzanna, R., and J. T. Coyle (1978) Dopamine- $\beta$-hydroxylase in rat submandibular ganglion cells which lack norepinephrine. Brain Res. 151: 206-214.

Gu, J., J. M. Polak, H. C. Su, M. A. Blank, J. F. B. Morrison, and S R. Bloom (1984) Demonstration of paracervical ganglion origin for the vasoactive intestinal peptide-containing nerves of the rat uterus using retrograde tracing techniques combined with immunocytochemistry and denervation procedures. Neurosci. Lett. 51:377-382.

Helm, G., B. Ottesen. J. Fahrenkrug. J.-J. Larsen, Ch. Owman, N.-O. Sjöberg, B. Stolberg, F. Sundler, and B. Walles (1981) Vasoactive intestinal polypeptide (VIP) in the human female reproductive tract: Distribution and motor effects. Biol. Reprod. 25: 227-234.

Heym, C., M. Reinecke, E. Weihe, and W. G. Forssmann (1984) Dopamine-B-hydroxylase-, neurotensin-, substance $P_{-}$, vasoactive intestinal polypeptide- and enkephalin-immunohistochemistry of paravertebral and prevertebral ganglia in the cat. Cell Tissue Res. 235: $411-418$.

Howe, P. R. C.. J. C. Provis, J. B. Furness, M. Costa, and J. P. Chalmers (1981) Residual catecholamines in extrinsically dencrvated guineapig ileum. Clin. Exp. Pharmacol. Physiol. 8: 327-333.

Imai, H., H. Kimura, and T. Maeda (1982) A stable and simple method of "FAGLUPAGAS fixation" for catecholamines for routine examination. Acta Histochem. Cytochem. 15: 798-806.

Inyama, C. O., G. W. Hacker, J. Gu, D. Dahl, S. R. Bloom, and J. M Polak (1985) Cytochemical relationships in the paracervical ganglion (Frankenhäuser) of rat studicd by immunocytochemistry. Neurosci. Lett. 55: 311-316.

Johnson, M., D. Ross, M. Meyers, R. Ress, R. Bunge, E. Wakshull, and H. Burton (1976) Synaptic vesicle cytochemistry changes when cultured sympathetic neurones develop cholinergic interactions. Nature 262: 308-310.

Jonakait, G. M., K. A. Markey, M. Goldstein, and I. B. Black (1984) Transient expression of selected catecholaminergic traits in cranial sensory and dorsal root ganglia of the embryonic rat. Dev. Biol. 101: $51-60$.

Kanerva, L. (1972) Development, histochemistry and connections of the paracervical (Frankenhäuser) ganglion of the rat uterus. Acta Instum. Anat. Univ. Helsinki.: Suppl. 2.

Klemm, N.. D. R. Nassel, and N. N. Osbornc (1985) Dopamine- $\beta$ hydroxylase-like immunoreactive neurons in two insect spccics, $\mathrm{Cal}$. liphora erythrocephala and Periplaneta americana. Histochemistry 83: $159-164$

Landis, S. C., and D. Keefe (1983) Evidence for neurotransmitter plasticity in vivo: Developmental changes in propertics of cholinergic sympathetic neurons. Dev. Biol. 98: 349-372.

Lindh. B., T. Hökfelt, L.-G. Elfvin, L. Terenius, J. Fahrenkrug, R. Elde, and M. Goldstein (1986) Topography of NPY-, somatostatin- and VIP-immunoreactive neuronal subpopulations in the guinea-pig celiac-superior mesenteric ganglion and their projection to the pylorus. J. Neurosci. 6: 2371-2383.

Lundberg. J. M. (1981) Evidence for coexistence of vasoactive intestinal polypeptide (VIP) and acetylcholine in neurons of cat exocrine gland. Morphological, biochemical and functional studies. Acta Physiol. Scand. (Suppl.) 496: 1-57.

Lundberg, J. M., A. Anggard, and J. Fahrenkrug (1981) Complementary role of vasoactive intestinal polypeptide (VIP) and acetylcholine for cat submandibular gland blood flow and secretion. I. VIP relcasc. Acta Physiol. Scand. 113: 317-327.

Lundberg, J. M., T. Hökfelt, A. Ånggård, L. Terenius, R. Elde, K. Markey, and M. Goldstcin (1982a) Organization principles in the peripheral sympathetic nervous system: Subdivisions by coexisting peptides (somatostatin, avian pancreatic polypeptide and vasoactive intestinal polypeptide-like immunoreactive materials). Proc. Natl. Acad. Sci. USA 79: 1303-1307. 
Lundberg, J. M., L. Terenius, T. Hökfelt, C. R. Martling, K. Tatemoto, V. Mutt, J. Polak, S. Bloom, and M. Goldstein (1982b) Neuropeptide Y (NPY)-like immunoreactivity in peripheral noradrenergic neurons and effects of NPY on sympathetic function. Acta Physiol. Scand. 116: 477-480.

Lundberg, J. M., A. Ånggård, E. Theodorsson-Norheim, and J. Pernow (1984) Guanethidine-sensitive release of neuropeptide Y-like immunoreactivity in the cat spleen by sympathetic nerve stimulation. Neurosci. Lett. 52: 175-180.

Lundberg, J. M., J. Pernow, K. Tatemoto, and C. Dahlof (1985) Preand postjunctional effects of NPY on sympathetic control of rat femoral artery. Acta Physiol. Scand. 123: 511-513.

Maccarrone, $C_{\text {. }}$, and $B$. Jarrott (1985) Differences in regional brain concentrations of neuropeptide $\mathrm{Y}$ in spontaneously hypertensive $(\mathrm{SH})$ and Wistar-Kyoto (WKY) rats. Brain Res. 345: 165-169.

Macrae, I. M., J. B. Furness, and M. Costa (1986) Distribution of subgroups of noradrenaline neurons in the coeliac ganglion of the guinea-pig. Cell Tissue Res. 244: 173-180.

Malmfors, T. (1965) Studies in adrenergic nerves. Direct observations on their distribution in an effector system, degeneration, and mechanisms for uptake, storage and release of catecholamines. Ph.D. thesis, Karolinska Institute, Stockholm, Sweden.

Mattiasson, A., E. Ekblad, F. Sundler, and B. Uvelius (1985) Origin and distribution of neuropeptide $\mathrm{Y}$-, vasoactive intestinal polypeptide- and substance P-containing nerve fibres in the urinary bladder of the rat. Cell Tissue Res. 239: 141-146.

Morris, H. R., M. Panico, T. Etienne, J. Tippins, S. J. Girgis, and I. MacIntyre (1984) Isolation and characterization of human calcitonin gene-related peptide. Nature 305: 746-748.

Morris, J. L., I. L. Gibbins, J. B. Furness, M. Costa, and R. Murphy (1985) Co-localization of neuropeptide $Y$, vasoactive intestinal polypeptide and dynorphin in non-noradrenergic axons of the guinea-pig uterine artery. Neurosci. Lett. 62: 31-37.

Morris, J. L., I. L. Gibbins, M. Costa, J. B. Furness, and R. Murphy (1986a) Non-noradrenergic axons containing both NPY and VIP in the guinea-pig uterine artery react with antisera to $\mathrm{DBH}$ after 6-hydroxydopamine treatment. Neurosci. Lett. (Suppl.) 23: S67.

Morris, J. L., I. L. Gibbins, G. Campbell, R. Murphy, J. B. Furness, and M. Costa (1986b) Innervation of the large arteries and heart of the toad (Bufo marinus) by adrenergic and peptide-containing neurons. Cell Tissue Res. 243: 171-184.

Morris, J. L., R. Murphy, J. B. Furness, and M. Costa (1986c) Partial depletion of neuropeptide $Y$ from noradrenergic perivascular and cardiac axons by 6 -hydroxydopamine and reserpine. Reg. Pept. 13: 147-162.

Morris, J. L., I. L. Gibbins, and R. Murphy (1986d) Neuropeptide Y-like immunoreactivity is absent from most perivascular noradrenergic axons in a marsupial, the brush-tailed possum. Neurosci. Lett. 71: 264-270.

Muller, B. D., T. Harris, C. Borri Voltattorni, and C. Bell (1984) Distribution of neurones containing dopa decarboxylase and dopamine$\beta$-hydroxylase in some sympathetic ganglia of the dog: A quantitative study. Neuroscience 11: 733-740.

Owman, Ch., and N.-O. Sjöberg (1966) Adrenergic nerves in the female genital tract of the rabbit. With remarks on cholinesterase-containing structures. Z. Zellforsch. Mikrosk. Anat. 74: 182-197.
Owman, Ch., E. Rosengren, and N.-O. Sjöberg (1967) Adrenergic innervation of the human female reproductive organs: $\Lambda$ histochemical and chemical investigation. Obstet. Gynecol. 30: 763-773.

Owman, C., P. Alm, and N.-O. Sjöberg (1983) Pelvic autonomic ganglia: Structure, transmitters, function and steroid influence. In Aulvnomic Ganglia, L.-G. Elfvin, ed., pp. 125-143, Wiley, Chichester, UK.

Papka, R. E., J. P. Cotton, and H. H. Traurig (1985) Comparative distribution of neuropeptide tyrosine-, vasoactive intestinal polypeptide-, substance P-immunoreactive, acetylcholinesterase-positive and noradrenergic nerves in the reproductive tract of the female rat. Cell Tissue Res. 242: 475-490.

Park, D. H. G. Teitelman, M. J. Evinger, J. I. Woo, D. A. Ruggiero, V. R. Albert, E. E. Baetge, V. M. Pickel, D. J. Reis, and T. H. Joh (1986) Phenylethanolamine $N$-methyltransferase-containing neurons in rat retina: Immunohistochemistry, immunochemistry and molecular biology. J. Neurosci. 6: 1108-1113.

Patterson, P. H. (1978) Environmental determination of autonomic transmitler functions. Annu. Rev. Neurosci. 1: 1-17.

Potter, D. D., S. C. Landis, S. G. Matsumoto, and E. J. Furshpan (1986) Synaptic functions in rat sympathetic neurons in microcultures. II. Adrenergic/cholinergic dual status and plasticity. J. Neurosci. 6: 10801098.

Rosengren, E., and N.-O. Sjöberg (1967) The adrenergic nerve supply to the female reproductive tract of the cat. Am. J. Anat. 121: 271284.

Ross, C. A., D. A. Ruggiero, M. P. Meeley, D. H. Park, T. H. Joh, and D. J. Reis (1984) A new group of neurons in hypothalamus containing phenylethanolamine $N$-methyltransferase (PNMT) but not tyrosine hydroxylase. Brain Res. 306: 349-353.

Rush, R. A., and L. B. Geffen (1980) Dopamine- $\beta$-hydroxylase in health and disease. CRC Crit. Rev. Clin. Lab. Sci. 12: 241-277.

Schultzberg, M., T. Hökfell, J. M. Lundberg, C. J. Dalsgaard, and L.-G. Elfvin (1983) Transmitter histochemistry of autonomic ganglia. In Autonomic Ganglia, L.-G. Elfvin, ed., pp. 205-233, Wiley, Chichester, UK.

Sjöberg, N.-O. (1967) The adrenergic transmitter of the female reproductive tract: Distribution and functional changes. Acta Physiol. Scand. (Suppl.) 305: 1-32.

Teitelman, G., T. H. Joh, and D. J. Reis (1978) Transient expression of a noradrenergic phenotype in cells of the rat embryonic gut. Brain Res. 158: 229-234.

Teitelman, G., M. D. Gershon, T. B. Rothman, T. H. Joh, and D. J. Reis (1981) Proliferation and distribution of cells that transiently express a catecholaminergic phenotype during development in mice and rats. Dev. Biol. 86: 348-355.

Teitelman, G., T. H. Joh, L. Grayson, D. H. Park, D. J. Reis, and L. Iacovitti (1985) Cholinergic neurons of the chick ciliary ganglia express adrenergic traits in vivo and in vitro. J. Neurosci. 5: 29-39.

Thorbert, G., P. Alm, Ch. Owman, and N.-O. Sjöberg (1977) Regional distribution of autonomic nerves in guinea-pig uterus. Am. J. Physiol. 233: C25-C34.

Yokota, R., and G. Burnstock (1983) Synaptic organisation of the pelvic ganglion of the guinea-pig. Cell Tissue Res. 232: 379-397. 